\title{
The impact of the use of collision exercises on some physical variables and the level of performance in some skills of throwing legs Ashi-waza players judo "Dr/ Ahmed Mohamed Nour El Din
}

Introduction and research problem

Judo is one of the individual sports skates, which is a sport that is characterized by the strength and beauty of movement, which require special physical and technical variables, and is based on specifications in which practitioners are subject to laws and rules to enable players to perform the skills properly and according to the requirements and performance characteristics of each skill

As the science of training progresses, a number of modern training methods have emerged in the field of sports training. These include collision training.

The American Society of Sports Medicine points out that crash training is a safe and useful exercise as well as a fun activity and improves the dynamic ability of its practitioners. : 6)
The concept of crash training is attributed to an expert from the former Soviet Union, Verkhanski, who launched this type of training with Shock Training, also known as Reactive Strength, and derived from the nature of the Balometrk exercises.

Donald Shaw (2008) points out that the intensity of the crash training has a direct effect on the musculoskeletal system and connective tissue $(15: 3,4)$

Collision training is a set of exercises designed to develop muscle elasticity through the so-called elongation and shortening cycle' It is a special method for developing explosive ability and depends on the moments of wrestling and braking that occur as a result of the weight of the body in its dynamic movement such as jump back The development of muscle capacity thus improves the

Instructor, Sports Training Department, Faculty of Physical Education, Sohag University. 
dynamic performance of movements. (24: 380)

Gabbetta.v (2009) points out that crash training is a concentrated muscle activity to improve the level of strength based on a physiological fact that the muscle can exert greater force or effort if it is prolonged before movement. Read (2002) indicates that collision training stimulates force in training movements by exploiting motor activity resulting from a heavy load in reversing the muscles.

Talha Hussein (1997) confirms Wilson that exercises based on elastic energy and the work of sensory receptors are most beneficial to reduce the length of time between lengthening and shortening.

The energy stored in the muscles as a result of lengthening comes out at rapid rates during the contraction phase and participates in moments The first of the second (8:43)

Yasser Yousef (2005) points out that the rise in the level of fitness elements is the basic pillar that enables the player to perform the basic conditions and some skills in shooting Judo (12: 17)
The judo sport requires its practitioners to perform motor skills with a specific specification that is characterized by a precise technical technique that requires special mobility and abilities.

Artistic performance in Judo is based on principles and scientific foundations, and requires harmonious motor responses $(9: 14)$

Ahmed Abu Al-Fadl (2006) and Sulaiman Ibrahim (2000) agree that Judo is an art.

The goal is to drop the opponent on the back with strength and speed or to fix it for 25 seconds or surrender as a result of a choke or break skill (2:16) (32: 7)

Through the experience of the researcher in the academic field and the field of training in judo sport, he found that the exercises used to develop muscle strength and muscular strength in judo training is traditional and noninteresting,

Which affects the players a negative impact and does not achieve the training objective and there is an important in the development of the level of muscle strength of judo players Ashi-waza has 
noticed that most of the training programs for judo sport develop the level of muscle strength in general and do not focus on parts without the other so that players can play judo weakness in some elements of physical fitness with the skills of throwing the two legs in spite of its importance as one of the important skills in judo through which the opponent can be overcome and this is what prompted the researcher to do this study to identify the impact of the use of collision exercises on some physical variables and the level of performance of some of the skills of throwing Ashi-waza players with judo players.

\section{Research goal}

The aim of the research is to identify the effect of the use of crash training on some physical variables and the level of performance of some skills of throwing Ashi-waza players in judo players

\section{Research hypotheses}

- There are statistically significant differences between the averages of pre and post measurements at the level of some physical variables and the level of performance of some skills of throwing Ashiwaza legs in judo players experimental research group.

- There are statistically significant differences between the averages of pre and post measurements at the level of some physical variables and the level of performance of some skills of throwing Ashiwaza legs in judo players control group.

- There are statistically significant differences between the averages of the two dimensions of the experimental and control groups in the level of some physical variables and the level of performance of some skills of throwing Ashiwaza players in the judo players and in favor of the experimental research group.

\section{Research Plan and Procedures:}

To achieve the objectives of the research and test hypotheses follow the following steps:

First:

Research

\section{Methodology:}

The researcher used the experimental method because of its suitability to the nature of the research using experimental design. The two groups are equal, one experimental and one experimental.

\section{Second: Society and Research Sample:}

The research community included the quality of youth at Sohag Sports Club and participants in the National Sports Project for the training season (2016-2017) and 
registered with the Egyptian Judo Federation.

The researcher chose the sample of the research in a deliberate manner from the youth of the age group (13-14 years) (8) emerging from the research community and outside the original sample to calculate the scientific transactions of the tests in question, as well as conducting exploratory studies on the research.

\section{My search group parity:}

The researcher found the parity between the experimental and control groups in light of the following variables: Anthropometric measures of age, height, weight, training age, and physical variables. Ashi-waza skills are under consideration and Table (2) shows this.

\section{Table (1)}

Equivalence of experimental and control groups at the level of some physical variables And the skills of shooting Ashi-waza

$\mathrm{N}=\mathrm{N}=\mathbf{2}=\mathbf{1 2}$

\begin{tabular}{|c|c|c|c|c|c|c|c|}
\hline \multirow{2}{*}{\multicolumn{2}{|c|}{ Variables }} & \multirow{2}{*}{$\begin{array}{c}\text { Measurement } \\
\text { unit }\end{array}$} & \multicolumn{2}{|c|}{$\begin{array}{c}\text { Experimental } \\
\text { group }\end{array}$} & \multicolumn{2}{|c|}{ Control group } & \multirow{2}{*}{$\begin{array}{c}\mathbf{T} \\
\text { valve }\end{array}$} \\
\hline & & & SMA & $\begin{array}{l}\text { standard } \\
\text { deviation }\end{array}$ & SMA & $\begin{array}{l}\text { standard } \\
\text { deviation }\end{array}$ & \\
\hline \multirow{3}{*}{$\begin{array}{l}\text { Physical } \\
\text { variables }\end{array}$} & $\begin{array}{l}\text { Muscle } \\
\text { strength } \\
\text { of the } \\
\text { legs }\end{array}$ & $\mathrm{kg}$ & 63.54 & 0.25 & 63.64 & 0.21 & 0.39 \\
\hline & $\begin{array}{l}\text { Muscle } \\
\text { strength } \\
\text { of the } \\
\text { muscles } \\
\text { of the } \\
\text { legs }\end{array}$ & M & 2.10 & 0.19 & 2.16 & 0.22 & 0.85 \\
\hline & $\begin{array}{l}\text { Muscular } \\
\text { capacity } \\
\text { of the } \\
\text { back } \\
\text { muscles }\end{array}$ & No. /s & 25.62 & 1.02 & 25.51 & 0.67 & 0.25 \\
\hline
\end{tabular}

Follow Table (1) 
Equivalence of experimental and control groups at the level of some physical variables And the skills of shooting Ashi-waza

$$
\mathbf{N}=\mathbf{N}=\mathbf{2}=12
$$

\begin{tabular}{|c|c|c|c|c|c|c|c|}
\hline \multirow{2}{*}{\multicolumn{2}{|c|}{ Variables }} & \multirow{2}{*}{$\begin{array}{c}\text { Measurement } \\
\text { unit }\end{array}$} & \multicolumn{2}{|c|}{$\begin{array}{c}\text { Experimental } \\
\text { group }\end{array}$} & \multicolumn{2}{|c|}{ Control group } & \multirow{2}{*}{$\begin{array}{c}\text { T } \\
\text { valve }\end{array}$} \\
\hline & & & SMA & $\begin{array}{l}\text { standard } \\
\text { deviation }\end{array}$ & SMA & $\begin{array}{l}\text { standard } \\
\text { deviation }\end{array}$ & \\
\hline & $\begin{array}{l}\text { Muscle } \\
\text { strength } \\
\text { of the } \\
\text { back } \\
\text { muscles }\end{array}$ & $\mathrm{Kg}$ & 61.52 & 0.85 & 61.22 & 0.28 & 0.63 \\
\hline \multirow{2}{*}{$\begin{array}{l}\text { The } \\
\text { skills of } \\
\text { throwing } \\
\text { the legs }\end{array}$} & D H pray & Degree & 5.50 & 0.58 & 5.65 & 0.61 & 0.52 \\
\hline & $\begin{array}{l}\text { Osoto } \\
\text { gary }\end{array}$ & Degree & 5.24 & 0.63 & 5.30 & 0.14 & 0.32 \\
\hline
\end{tabular}

Value $(\mathrm{T})$ at significance level $(0.05)=1.711$

Table (2) shows that there are no statistically significant differences between the averages of pre measurements in the experimental and control groups.

The calculated value $(\mathrm{t})$ is less than the tabular value, indicating the equivalence of the two research groups in the variables under consideration.

Tests used in research:

Search tools and devices:

- The researcher used the following tools and devices:

- Youth registration form and test results: Attachment (1)

- Medical balance to measure weight in kilograms.
- Resitmeter to measure length in centimeters

- Tools (Judo rug - different weight)

- Devices (dynamometer manometer - video camera)

\section{Tests used in research:}

- Dynamometer to measure the muscle strength of the legs.

- Wide jump of stability to measure the muscular strength of the legs.

- Test the lifting of the alarm on top of the abdomen to measure the muscular strength of the back muscles.

- Dynamometer for measuring muscle strength back.

\section{Coaching Program:}

The researcher developed the program of the collision 
exercises after a reference analysis of the scientific references (3), (5), (11), (19), (21), (23) and Arabic and foreign information network.

Principles of program design:

- Provide the tools and equipment's which required to implement the search procedures.

- Number of training units, unit time and time distribution of the training module.

- Appropriate configuration of components of the training load and the gradation of the program loads and training module.

- Provide the elements of diversity and suspense in the activities and exercises used to introduce pleasure and joy in performance.

- Gradient performance from easy to hard, simple to composite.

- Consider the heavy load gradient throughout the proposed program.

- Link physical and skill aspects during the performance of the content of the implementation of the program.

Distribution of daily unit time in the crash training program:
The researcher divided the time of the training unit into three sections. The content of the daily training unit was distributed as well as the formation of the training load and the distribution of the training activities on the daily and weekly training units during the preparation period.

After the researcher studied many references, researches and previous studies in the field of training in general, judo in particular, On the pre measurement of the research sample, the researcher is able to connect to the following:

- Total program time (8) eight weeks

- Number of training units during the week (3) three units.

- The total number of units (24) twenty-four training units.

The researcher divided the implementation period into three stages.

- The general preparation stage lasted (12) units.

- Special preparation stage and took (9) units.

- Pre-competitions and took (3) units.

View and discuss the results 
Table (2)

The significance of the differences and the rates of improvement between the averages of the pre measurements at the level of some physical variables and the level of performance of some skills of Ashi-waza Judo players experimental search group $\mathrm{N}=12$

\begin{tabular}{|c|c|c|c|c|c|c|c|c|c|}
\hline \multirow[t]{2}{*}{ Tests } & \multirow[t]{2}{*}{$\begin{array}{c}\text { Measurement } \\
\text { units }\end{array}$} & \multicolumn{2}{|c|}{$\begin{array}{c}\text { Pre } \\
\text { measurement }\end{array}$} & \multicolumn{2}{|c|}{$\begin{array}{c}\text { Post } \\
\text { measurement }\end{array}$} & \multirow{2}{*}{$\begin{array}{l}\text { Difference } \\
\text { between } \\
\text { the two } \\
\text { averages }\end{array}$} & \multirow[t]{2}{*}{$\begin{array}{l}\text { Improvement } \\
\text { rate }\end{array}$} & \multirow[t]{2}{*}{$\begin{array}{l}\text { Value }(\mathrm{T}) \\
\text { Calculated }\end{array}$} & \multirow[t]{2}{*}{$\begin{array}{l}\text { Level of } \\
\text { significance }\end{array}$} \\
\hline & & S & $\pm \mathrm{E}$ & S & $\pm \mathrm{E}$ & & & & \\
\hline $\begin{array}{l}\text { Muscle } \\
\text { strength of } \\
\text { the legs }\end{array}$ & $\mathrm{Kg}$ & 63.54 & 0.25 & 72.32 & 0.52 & 8.78 & $12.14 \%$ & 4.98 & Significance \\
\hline $\begin{array}{l}\text { Muscle } \\
\text { strength of } \\
\text { Significance } \\
\text { the muscles } \\
\text { of the legs }\end{array}$ & M & 2.10 & 0.19 & 2.25 & 0.25 & 0.15 & $6.66 \%$ & 4.65 & Significance \\
\hline $\begin{array}{l}\text { Muscular } \\
\text { capacity of } \\
\text { the back } \\
\text { muscles }\end{array}$ & No.IS & 25.62 & 1.02 & 31.20 & 0.63 & 5.58 & $17.88 \%$ & 4.69 & Significance \\
\hline $\begin{array}{l}\text { Muscle } \\
\text { strength of } \\
\text { the back } \\
\text { muscles }\end{array}$ & $\mathrm{Kg}$ & 61.52 & 0.85 & 68.65 & 0.32 & 7.13 & $10.38 \%$ & 4.56 & Significance \\
\hline D H pray & Degree & 5.50 & 0.58 & 7.98 & 0.47 & 2.48 & $31.07 \%$ & 4.78 & Significance \\
\hline Osoto gary & Degree & 5.24 & 0.63 & 8.65 & 0.65 & 3.41 & $39.42 \%$ & 4.62 & Significance \\
\hline
\end{tabular}

Value $(\mathrm{T})$ at significance level $(0.05)=1.782$

Table (2) shows that there are

The performance of some skills statistically significant differences between the of throwing Ashi-waza legs averages of the pre and post measurements of the experimental group in the tests of the physical variables. for the benefit of post where the value of $(\mathrm{T})$ is calculated greater than its tabular value at the significance level (0.05)

Assiut Journal For Sport Science Arts 
Table (3)

Significance of differences and improvement rates between the averages of pre measurements at the level of some physical variables and the level of performance of some skills of throwing legs Ashi-waza Judo players control search group $\mathrm{N}=12$

\begin{tabular}{|c|c|c|c|c|c|c|c|c|c|}
\hline \multirow[t]{2}{*}{ Tests } & \multirow{2}{*}{$\begin{array}{c}\text { Measurement } \\
\text { units }\end{array}$} & \multicolumn{2}{|c|}{ Pre measurement } & \multicolumn{2}{|c|}{$\begin{array}{c}\text { Post } \\
\text { measurement }\end{array}$} & \multirow{2}{*}{$\begin{array}{l}\text { Difference } \\
\text { between } \\
\text { the two } \\
\text { averages }\end{array}$} & \multirow{2}{*}{$\begin{array}{c}\text { Improvement } \\
\text { rate }\end{array}$} & \multirow{2}{*}{$\begin{array}{l}\text { Value }(\mathrm{T}) \\
\text { Calculated }\end{array}$} & \multirow{2}{*}{$\begin{array}{c}\text { Level of } \\
\text { significance }\end{array}$} \\
\hline & & S & $\pm \mathrm{E}$ & $S$ & $\pm \mathrm{E}$ & & & & \\
\hline $\begin{array}{l}\text { Muscle } \\
\text { strength of } \\
\text { the legs }\end{array}$ & $\mathrm{Kg}$ & 63.64 & 0.21 & 66.36 & 0.63 & 2.72 & $4.098 \%$ & 3.21 & Significance \\
\hline $\begin{array}{l}\text { Muscle } \\
\text { strength of } \\
\text { Significance } \\
\text { the muscles } \\
\text { of the legs }\end{array}$ & M & 2.16 & 0.22 & 2.22 & 0.21 & 0.06 & $2.702 \%$ & 3.28 & Significance \\
\hline $\begin{array}{l}\text { Muscular } \\
\text { capacity of } \\
\text { the back } \\
\text { muscles }\end{array}$ & No.IS & 25.51 & 0.67 & 27.32 & 0.85 & 1.81 & $6.62 \%$ & 3.10 & Significance \\
\hline $\begin{array}{l}\text { Muscle } \\
\text { strength of } \\
\text { the back } \\
\text { muscles }\end{array}$ & $\mathrm{Kg}$ & 61.22 & 0.28 & 64.52 & 0.22 & 3.30 & $5.11 \%$ & 3.17 & Significance \\
\hline D H pray & Degree & 5.65 & 0.61 & 7.10 & 0.17 & 1.45 & $25.66 \%$ & 3.64 & Significance \\
\hline Osoto gary & Degree & 5.30 & 0.14 & 7.29 & 0.32 & 1.99 & $27.29 \%$ & 3.20 & Significance \\
\hline
\end{tabular}

Value $(\mathrm{T})$ at significance level $(0.05)=1.782$

Table

statistically

(3) significant differences between mean and post measurements of the control group in tests of physical variables and performance of some skills of throwing Ashi-waza in favor of post.

The calculated value of $(t)$ is greater than the tabular value at the significance level (0.05) 
Table (4)

The significance of the differences and the rates of improvement between the averages of the dimensional measurements in the experimental and control groups at the level of some physical

variables and the level of performance of some skills The two legs are shot ashi-waza $\mathrm{N}=\mathrm{N}=2=12$

\begin{tabular}{|c|c|c|c|c|c|c|c|}
\hline \multirow[t]{2}{*}{ Tests } & \multirow[t]{2}{*}{$\begin{array}{c}\text { Measurement } \\
\text { units }\end{array}$} & \multicolumn{2}{|c|}{$\begin{array}{l}\text { The experimental } \\
\text { group }\end{array}$} & \multicolumn{2}{|c|}{$\begin{array}{l}\text { Control } \\
\text { group }\end{array}$} & \multirow[t]{2}{*}{$\begin{array}{c}\text { Value (T) } \\
\text { Calculated }\end{array}$} & \multirow[t]{2}{*}{$\begin{array}{c}\text { Level of } \\
\text { significance }\end{array}$} \\
\hline & & $\mathrm{S}$ & $\pm \mathrm{E}$ & $S$ & $\pm \mathrm{E}$ & & \\
\hline $\begin{array}{l}\text { Muscle } \\
\text { strength of the } \\
\text { legs }\end{array}$ & No. & 72.32 & 0.52 & 66.36 & 0.63 & 3.17 & Significance \\
\hline $\begin{array}{l}\text { Muscle } \\
\text { strength of } \\
\text { Significance } \\
\text { the muscles of } \\
\text { the legs }\end{array}$ & M & 2.25 & 0.25 & 2.22 & 0.21 & 4.18 & Significance \\
\hline $\begin{array}{l}\text { Muscular } \\
\text { capacity of the } \\
\text { back muscles }\end{array}$ & No $\backslash \mathrm{s}$ & 31.20 & 0.63 & 27.32 & 0.85 & 3.69 & Significance \\
\hline $\begin{array}{l}\text { Muscle } \\
\text { strength of the } \\
\text { back muscles }\end{array}$ & Nols & 68.65 & 0.32 & 64.52 & 0.22 & 4.98 & Significance \\
\hline D H pray & $\mathrm{S}$ & 7.98 & 0.47 & 7.10 & 0.17 & 4.59 & Significance \\
\hline Osoto gary & S & 8.65 & 0.65 & 7.29 & 0.32 & 4.16 & Significance \\
\hline
\end{tabular}

Value $(\mathrm{T})$ at significance level $(0.05)=1.711$

Table

4

significant

statistically

shows

differences between mean

distance measurements in experimental and control groups in tests of physical variables.

The performance of some Ashi-waza skills in favor of post where the calculated value $(t)$ is greater than the tabular value at the significance level (0.05)

\section{Discussion of results}

Table (3) shows the existence of differences of statistical significance in the level of physical and skill variables in the level of some physical variables and the level of performance of some skills of throwing Ashi-waza legs

The researcher attributed this result to the nature of the proposed training program, which is characterized by 
speed and strength in performance and this is a prerequisite for skill Judo The two legs also play a key role in the imbalance of the opponent after the start and this is what the researcher was surprised when choosing the training exercises in a manner commensurate with the skills of throwing Ashi-waza legs.

This is confirmed by Ali Fahmi (2015) (10) and Abo ElOla Abdel-Fattah (1997). (1) Special exercises must match their construction and strength with competition movements. Power exercises should focus on the movements of the contractions of competitive exercises in order to achieve the special harmony of performance requirements.

The researcher explained that the exercises that work on the length of the involuntary muscles of the material joints that work to generate muscle contraction of the voluntary works to excite other sensory organs and thus increase the number of motor units in the muscles working on these joints, which is a necessity to increase muscle strength as well as match collisions with Performance format.

According to Abu ElOla Abdel-Fattah (1997), muscular strength training increases significantly in the case of increasing the motor range of the joint.

It helps to use the properties of the elastic components of the muscle to achieve muscular balance of the joints (2: 247 , 249)

Strength training should meet individual needs and the most appropriate training for muscles is to repeat the type of work to a number of times required by the skill and are properly strengthened and are more resistant to injury. (32:2)

This is consistent with Nadi Ramah (2008) that these exercises aim to produce the largest strength in the shortest possible time, so that the time of contact with the feet of the earth is shortened. (11: 53)

This is what Muhammad Jabir Barka (2009) points out, that the effect of gravitational forces on the body leads to the emergence of a new force 
known as the force of weight, a natural force connected to the body's connection to the surface of the earth.

Thus, the first hypothesis has been achieved, which states that there are statistically significant differences between the averages of pre and post measurements at the level of some physical variables and the level of performance of some skills of firing Ashi-waza players in judo players.

Table (4) shows statistically significant differences between the mean and post measurements of the control group in the physical variables tests.

The skills of throwing Ashi-waza in favor of the telemetry where the value of $(\mathrm{t})$ is greater than the tabular value at the level of significance (0.05) The result is the regularity of the research sample in physical and skill training.

The relationship

between the basic skills of a sport and its different physical requirements (general, special) is a close relationship that must be taken into account in the preparation of the players, and that there is no separation between the physical and the physical preparations.

On the contrary, The physical elements are developed in accordance with skill requirements, which is successful in the training process and thus the level of the players. When the player has a high physical qualities can perform all the skills well. (48: 1)

This is confirmed by the "Gold Smith" (2003) that the success in any basic skill of defense or offensive needs to develop the necessary physical components contribute to the performance of the ideal and that each basic skill contributes to the performance by nature more than a physical component)

Thus, the second hypothesis was achieved, which states that there are statistically significant differences between the averages of pre and post measurements at the level of some physical variables and 
the level of performance of some skills of throwing Ashiwaza legs in judo players control group.

It is clear from Table (5) that there are statistically significant differences between mean distance measurements in the experimental and control groups in the tests of physical variables and the level of performance of some skills of throwing Ashi-waza legs for the benefit of post where the value of ( $t$ ) calculated greater than their tabular value at the level of significance 0.05 ).

The researcher attributed this result to the experimental group's progress on the control group's beginners to use the collision training applied to the experimental group.

The researcher also took care of the muscles and flexibility of the joints so that the muscles and joints become ready to perform the crash training efficiently without injury.

The collision training also improves the muscular ability of the two legs. This clearly shows the improvement of the physical variables and the skills of firing the two legs in the experimental group from the control group.

In the opinion of the researcher that the collision training led to shortening the time of contraction of muscle fibers and improved compatibility between working muscles and muscles

The researcher observed in the design of collisions shortening the time of contact with the feet or arms of the ground and confirms that Gabita (2001) (17) The results of this study with what reached Nadi Hamed Ramah (2008) (11) The crash training contributes to the development of muscular strength of the arms and legs and this is confirmed by this study that the training exercises improve muscle capacity and positively affect the improvement of the skill performance

Thus, the third hypothesis has been achieved, which states that there are statistically significant differences between the averages of the two dimensions 
of the experimental and control groups in the level of some physical variables and the level of performance of some skills of throwing Ashi-waza players in judo players and for the experimental research group

\section{Conclusions}

- The impact of the use of collisions on the level of physical characteristics of the judo beginners experimental research group.

- The impact of the use of training exercises on the level of skill skills of throwing Ashiwaza legs in judo players.

- The impact of the use of training exercises better than physical and skill training in improving the physical and skill of the Judo.

\section{Recommendations}

- Use of the proposed exercises because of their positive impact in improving the physical and skill qualities of judo skills.

- Conduct similar studies on the impact of crash training on other skills.

- Conducting training courses for judo trainers on the importance of using the training exercises for young people.

\section{References}

1- Abdel Halim Mohamed Abdel Halim (2011) Modern methods of teaching judo, Dar Al Wafa Printing and Publishing, Alexandria

\section{2- Abu El-Ola Abdel-Fattah} (1997): Sports training physiological bases, Dar AlFikr Al-Arabi, first edition, Cairo

\section{3- Ahmed Abu El Fadl} Hegazy (2006): Judo Theoretical and Applied Foundations, Amer for Printing and Publishing, Mansoura

4- Ali Fahmi al-Beek and others (2015): Methods of measuring anaerobic and aerobic capacities, knowledge facility of Alexandria.

\section{5- Alsokary, Mohammed} Jaber Bureka (2009): Biometric training for young people, Knowledge facility Alexandria, Part II

\section{6- American college of sports} medicine (2001): plyometric training for children and adolescent current comment USA 
7- Boron et al.(2000): Iso kinatic Dynamics Megements of quadricepps femurs and handsprings in female hand ball playas Elerir science publishers, B.V.S ports medicine and Health G.P.A humans Editor.

8- Donald ehu (2008): explosive power \&strength complex training for maximum results $\mathrm{K}$ human kinetic ,London.

9- Elham Abdel-Rahman, Naji Asaad (2002): "sportive training, scientific book, science of physical education and sports", a scientific book periodic, Bahrain Institute of Sports, the third issue.

10- Gabbetta.v (2009): plyometrices new studies in athletic for basic considerations new studies in athletics March USA.

11- Gambetta, $R$ (2001): Plyonetric training, Track and Field $T$. manual new studies in athletics March USA

12- Gold Smith (2003): Speed us effort swimming science, swimming coach in formation, U.S.A.
13- Joseph, E.N.C. and charles, R.E. Brup (2002): Basic tale, Tic, bell human, London,

14- Maglischo ,E, W (2003): Swimming Faster, May Field Publishing co.Colifarnia

\section{5- Maron \& Meglym(2000)}

Dynamic strength training sports and fitness series, Brown publishers M.S.A,

\section{6- Nadi Hamed Rammah} (2008): "Effectiveness of the collision training on the development of muscular capacity and the level of performance of jumping inside with the individual of the two legs in the successor to the jumping horse in the light of the genetic diversity of the enzyme angiotensin converter (ACE)" Journal of Science and Sports Arts, Faculty of Physical Education for Girls, Cairo .

17- Read, M.Te et al (2002)

Caparison of Hamstring Quadriceps Isokincts Strength Rations and power in tennis, Squash and track athletes, British Journal of sports medicine Vol. 24 No.3, London, 


\section{5}

18- Rifai Mustafa Hassan (1994): "A study between the method of using weights and the method of confrontation to develop the strength of the two legs of football players" published research, the scientific journal - theories and applications Faculty of Physical Education for Boys University of Alexandria.

19- Risa N. Kharbit (2014):

Selected group in training and physiology of sport, book center for publishing, Cairo.

20- Schibert, M, (2002): Competitive swimming Techniques for champions, time I.N.C.
21- Sharkey, B.J (2000): Physiology of fitness.3rd human kinetic booksllions.

22- Sulaiman Ali Ibrahim (2000) Judo curriculum for first year students, unpublished memoirs

23- Talha Hossam El-Din, Wafaa Salah El-Din and Akheroun (1997): Encyclopedia of Sports Training Arab Thought House Cairo

24- Yasser Youssef Abdel Rouf (2005): Gymnastics and the twenty- first century, Dar Al- Sahab Publishing and Distribution, 3, Cairo. 